\title{
The care provided by the family to the premature newborn: analysis under Leininger's Transcultural Theory
}

\author{
O cuidado realizado pela família ao recém-nascido prematuro: análise sob a teoria transcultural de Leininger \\ El cuidado realizado por la familia al neonato prematuro: análisis bajo la teoría transcultural de Leininger
}

Ana Celi Silva Torres Nascimento'
ORCID: 0000-0003-2738-6110

Aisiane Cedraz Morais' ORCID: 0000-0001-9547-6914

Rita da Cruz Amorim' ORCID: 0000-0001-8782-2151

Deisy Vital dos Santos" ORCID: 0000-0002-2312-3586

'Universidade Estadual de Feira de Santana. Feira de Santana, Bahia, Brazil.

"Universidade Federal do Recôncavo da Bahia. Cruz das Almas, Bahia, Brazil.

How to cite this article:

Nascimento ACST, Morais AC, Amorim RC, Santos DV. The care provided by the family to the premature newborn analysis under Leininger's Transcultural Theory. Rev Bras Enferm. 2020;73(Suppl 4):e20190644 doi: http://dx.doi.org/10.1590/0034-7167-2019-0644

\section{Corresponding author:} Ana Celi Silva Torres Nascimento E-mail: celitorres19@hotmail.com

EDITOR IN CHIEF: Antonio José De Almeida Filho ASSOCIATE EDITOR: Ana Fátima Fernandes

Submission: 09-10-2019

Approval: 04-06-2020

\section{ABSTRACT}

Objective: To analyze the care practices of family members of premature infants admitted to a Neonatal Intensive Care Unit in the light of Leininger's transcultural theory. Methods: Qualitative, descriptive and exploratory study. Participant observation and semi-structured interviews were conducted with 16 family members of newborns, admitted to the neonatal unit of a public maternity hospital, during the months of May and June 2019. The software called Interface de R pour analyses Multidimensionnelles de Textes et de Questionnaire and the Bardin Content Analysis technique. Results: Two thematic categories emerged: Family care in the neonatal unit; (in)effective support for shared care. Conclusion: The participation of families in the care of babies is still unstable, but it must be an inseparable element of culturally congruent care, thus collaborating with the full recovery of the premature. Descriptors: Family; Premature New-born; Child Care; Hospitalization; Neonatal Intensive Care Units.

\section{RESUMO}

Objetivo: Analisar as práticas de cuidado dos familiares de prematuros internados em uma Unidade de Terapia Intensiva Neonatal à luz da teoria transcultural de Leininger. Método: Estudo qualitativo, descritivo e exploratório. Foram realizadas observação participante e entrevistas semiestruturadas com 16 familiares de recém-nascidos internados na unidade neonatal de uma maternidade pública, durante os meses de maio e junho de 2019. Utilizou-se o software denominado Interface de R pour analyses Multidimensionnelles de Textes et de Questionnaire" e a técnica Análise de Conteúdo de Bardin. Resultados: Emergiram duas categorias temáticas: Cuidado da família na unidade neonatal; Suporte (in)eficaz para o cuidado compartilhado. Conclusão: A participação das famílias no cuidado aos bebês ainda é instável, porém deve ser elemento indissociável do cuidado culturalmente congruente, colaborando, assim, com a recuperação integral do prematuro.

Descritores: Família; Recém-Nascido Prematuro; Cuidado da Criança; Hospitalização; Unidades de Terapia Intensiva Neonatal.

\section{RESUMEN}

Objetivo: Analizar las prácticas de cuidado de los familiares de prematuros internados en una Unidad de Terapia Intensiva Neonatal a la luz de la teoría transcultural de Leininger. Método: Estudio cualitativo, descriptivo y exploratorio. Han sido realizadas observación participante y entrevistas semiestructuradas con 16 familiares de neonatos internados en la unidad neonatal de una maternidad pública, durante los meses de mayo y junio de 2019. Se ha utilizado el software denominado Interface de R pour analyses Multidimensionnelles de Textes et de Questionnaire y la técnica Análisis de Contenido de Bardin. Resultados: Emergieron dos categorías temáticas: Cuidado de la familia en la unidad neonatal; Suporte (in)eficaz para el cuidado compartido. Conclusión: La participación de las familias en el cuidado a los bebés aún es inestable, sin embargo debe ser elemento indisociable del cuidado culturalmente congruente, colaborando, así, con la recuperación integral del prematuro.

Descriptores: Familia; Neonato Prematuro; Cuidado del Niño; Hospitalización; Unidades de Terapia Intensiva Neonatal. 


\section{INTRODUCTION}

For many families, the course of pregnancy and birth constitutes the fulfilment of a dream, with the expectation of a healthy child, able to preserve the values and specific characteristics of each family. However, the arrival of a child can cause several changes in the family environment, such as the acquisition of new roles and responsibilities by family members. In addition, there may be the appearance of emotional instability and vulnerability when the birth of a premature baby occurs, which may require intensive care in a Neonatal Intensive Care Unit or Conventional Neonatal Intermediate Care Unit (NICU — in Portuguese, Unidade de Cuidado Intermediário Neonatal Convencional [UCINCo]] ${ }^{(1-2)}$.

Hospitalization in a Neonatal Intensive Care Unit is both a challenging experience that causes varied impacts on the newborn (NB) and his family, which can generate an interruption in family dynamics, as well as a place that cares and saves lives ${ }^{(3-4)}$. This rupture of the family unit leads to an imbalance in its ability to function, so that conflicts arise, distance from its members and changes in its functioning dynamics ${ }^{(5-6)}$.

After the insertion of parents in children's hospitalization, care is no longer centered on the child, and their social and relational environment is valued, so that the child and the family are considered as a single client. Thus, the relevance of the family in caring for the child is recognized, the individuality of each member and their life histories are respected, assistance is given to each one in overcoming the doubts and difficulties of the child's illness period and allows recovery, reorganization and balance of the family that experiences hospitalization ${ }^{(7)}$.

These changes in the care model emerged with the implementation of the Kangaroo Method in Brazil, which is an individual intervention model based on the unique care of premature babies and their families. It encourages the proximity of skin-to-skin contact between newborn and premature parents for as long as they both find it pleasurable, favoring them to strengthen the affective bond and, furthermore, providing better child development ${ }^{(8)}$.

Therefore, it is essential to expand the care focus, expanding the attention of health professionals to families and other caregivers. In this direction, the Family-Centered Care model (FCC) recognizes the importance of the family in the context of care, guarantees everyone's participation in the planning of actions and decision-making, reveals a new way of caring where each family defines its own problems and needs. In addition, the FCC can offer resources to strengthen the family, stimulating its potential and promoting its autonomy ${ }^{(9)}$.

The positive effects of the practice of FCC in the neonatal environment are related to the decrease in the neonate's length of stay in the Neonatal Intensive Care Unit and readmissions, increased bond between NB and family, greater adherence to the kangaroo method and increased breastfeeding rates, beyond reducing parental stress and increasing self-confidence in the work performed by health professionals $s^{(10-11)}$. In addition, when parents have unrestricted access to their child's hospitalization and can follow all the procedures, they are able to better accept their health condition ${ }^{(12)}$.

Although there is recognition of the family as a care unit by health professionals, there is a gap between theoretical knowledge and clinical practice in a solid and systematic way. This is because the family needs to leave a secondary position, share power and walk in the opposite direction to the feelings of vulnerability, which is, therefore, also true for the family of the premature NB: it needs to be empowered in order to mitigate the damage of hospitalization ${ }^{(89)}$.

The family takes care from its references and reproduces in the hospital the care practices based on their beliefs, customs, resources and worldviews; however, these practices are not always compatible with the culture of care of health professionals ${ }^{(13)}$. Based on Leininger's theory, the nurse must be able to serve individuals in their entirety, respecting the cultural aspects of each family to develop culturally congruent care, in which the patient's culture is present in care planning ${ }^{(14)}$.

The relevance of this study consists of its unprecedented cut: through the survey of the state of the art, the descriptors in Portuguese "família", "pré-termo", " prematuro" and "transcultural"and, in English, "Family", "Preterm" "'Premature", "Transculture" besides the Boolean operator"and"; in the LILACS, SciELO, PubMed, MEDLINE and PePSIC databases; with a ten-year period of publication; including articles, dissertations and national and international theses. Ten publications were obtained, but all without articulation with the theme.

This research contributes to reflections in different contexts: in health services, as we position the family as the protagonist of newborn care in the NICU; it points out aspects that are essential for a family-centered care model; in the academic environment, it makes the professionals (re)think training in health courses that broadens the view of the premature and their family; and finally, with families and NR, who will be assisted from the perspective of cross-cultural care, being perceived beyond prematurity.

\section{OBJECTIVE}

To analyze the care practices of family members of premature newborns admitted to the Neonatal Intensive Care Unit in the light of Leininger's transcultural theory.

\section{METHODS}

\section{Ethical aspects}

All stages of this research were supported by Resolution $n^{\circ}$. 466/2012 of the National Health Council and approved by the Ethics and Research Committee on Human Beings at the State University of Feira de Santana.

\section{Theoretical methodological framework}

The use of nursing theories in the practice of nurses provides science-based care and has contributed to the construction of a field of knowledge. In this context, theories are instruments that serve as a guide for the performance of nurses in the areas of care, management, research and teaching, contributing to the acquisition of the profession's autonomy, social recovery and strengthening of nursing ${ }^{(15-16)}$.

To support the theoretical reflections on the care practices of families of premature infants in the NICU, Madeleine Leininger's cultural care theory (CCT) was chosen, because, among the nursing theories, it is the one that encompasses the idea of human 
care/caring in their differences and similarities in the different cultures of the world ${ }^{(17)}$. This theory appreciates cultural diversity and universality. It seeks to provide a form of care that is effective and originates from the needs of the individual, their family and cultural groups. These must be studied closely to enable a type of care that is culturally congruent with the needs of the population from the perspective of humanized care ${ }^{(13)}$.

Such theory is represented by the systematized and structured way in the Sunrise model, which portrays the phases of the nursing process, in which it displays the history, the recognition of the cultural situation and the actions of nursing care. This model aims to defend the importance and influence of the cultural dimension in the interconnection of care applied in nursing, which is essential for efficient and resolving assistance ${ }^{(15)}$.

For this research, the second level of the Sunrise model was delimited, which includes individuals, families and cultures in the health context, with emphasis on the determinants that influence the ways of caring, such as political, economic, religious, values and beliefs cultural, environmental and ethno-historical factors.

\section{Study Type}

It is a research with a qualitative, descriptive and exploratory approach, based on Leininger's transcultural theory. The survey followed the steps recommended by the Consolidated Criteria for Reporting a Qualitative Survey (COREQ) ${ }^{(18)}$.

\section{Methodological procedures}

\section{Study setting}

It is a NICU of the public maternity hospital in Feira de Santana, Bahia, Brazil, with a level of care of medium ambulatory and hospital complexity, specialized in urgent and obstetric emergencies, with the proposal of humanized assistance to women in the puerperal pregnancy cycle and to newborns.

\section{Data sources}

In this study, the concept of family was considered as that of a dynamic unit, united by ties of consanguinity and/or affection, considering close people (grandparents, neighbors and friends) as members of the family ${ }^{(19)}$. 16 interviews were carried out with relatives of premature infants admitted to the unit referred to. The inclusion criteria were: families of preterm NBs (NBs under 36 weeks and 6 days of gestation); hospitalized in the neonatal ICU for at least 7 days, considering it the ideal time of living in the environment to answer the question of the object of study. The following were excluded: families of premature infants who had some congenital malformation, as this condition implies specific practices and care. It is noteworthy that data saturation happened due to the understanding of the object of study through the statements of family members.

\section{Data collection and organization}

Data collection took place between May and June 2019, when participant observation, informal conversations and interaction with the families present in the Neonatal Intensive Unit were carried out, as well as the observation of the care practices carried out by them with children in the neonatal setting. For a greater understanding of contextual details and non-verbal expressions of the subject, the field diary was used as a recording instrument.

Still, semi-structured interviews were carried out, with an average duration of 18 minutes, in a reserved room under the coordination of the Kangaroo Neonatal Intermediate Care Unit (UCINCa) due to the unavailability of a room in the neonatal ICU. The choice for these collection techniques is justified, in this study, by the importance of the observation being able to elucidate or confront the data apprehended by the semi-structured interviews, allowing the understanding of the universe of family care with the hospitalized NB in the light of the transcultural theory.

The interview script consisted of four guiding topics regarding family participation in shared care for hospitalized premature newborns: "Tell me what it is like for you to have a premature child admitted to a neonatal ICU"; "Tell me what it is like for you to take care of a hospitalized premature child"; "Describe the care provided by lady (gentleman) within the Intensive Care Unit with her / his child"; "Tell me what or who helped sir or madam to take care of your child in the neonatal ICU".

To ensure methodological rigor, the interviews were recorded using an electronic/digital device with the authorization of the participants who agreed to participate in the research and after signing the appropriate terms: Free and Informed Consent Form (ICF), Term of Assent Free and Informed (TALE) and the Authorization of Responsibility Term, depending on the age group of the interviewee. To maintain anonymity, the fragments of each interviewed family member were encoded by the letter $\mathrm{E}$, followed by Arabic numerals to represent the order of participation (from E1 to E16).

\section{Data analysis}

Subsequently, the data were organized and analyzed by Bardin's Content Analysis method, following the three fundamental steps: pre-analysis, material exploration and treatment of results, which includes inference and interpretation ${ }^{(20)}$.

Another technique used in the interviews, after Bardin's analysis, was the use of the R Interface pour les Analyses Multidimensionnelles de Textes et de Questionnaires' (IRaMuTeQ ${ }^{\circ}$ ) software, a program that allows statistical analysis on textual corpus and on individual tables/words. It is anchored by the R software and the Python language $\mathrm{e}^{(21-22)}$. It is worth noting that this software is a data processing tool; thus, it performs a lexicographic analysis of the textual content, denoting breakdowns and classes that reveal the analysis categories evidenced in the subjects' statements ${ }^{(23)}$.

IRaMuTeQ ${ }^{\circ}$ allows the use of different technical resources for lexical analysis, of which the following stand out: classic lexical analyzes; specificity analysis; descending hierarchical classification method (DHC); similitude analysis; and word cloud. Thus, we opted for the "word cloud", which allows the grouping of words and organizes them graphically according to their frequency ${ }^{(21-22)}$.

Finally, to complement the data analysis, the empirical data were treated in the light of the theoretical framework adopted. After analysis, the results were thorough and exhaustively decoded, 
generating the following thematic categories: Family care in the neonatal unit and (in)effective support for shared care.

\section{RESULTS}

Directly participated in the study: 16 family members - 14 mothers, 1 father and 1 neighbor/friend of the family; and indirectly, other family members (mothers, fathers, grandparents) who were observed in the neonatal ICU setting. As for age, it ranged from 17 to 46 years. Regarding the location, 8 lived in Feira de Santana and 8 belonged to other municipalities. Regarding family income, 10 reported having a monthly income of 1 minimum wage, 3 had an income above 1 minimum wage, 1 had the benefit of the spouse and the assistance of "Family Bag" (state welfare) and 1 depended on the "Family Bag". These last two conditions (living in another municipality and low monthly income) hinder the presence of family members in the neonatal environment and emerge in the context of cross-cultural care to assess the presence of the family in this sector.

When using the IRaMuTeQ ${ }^{\circ}$ program, the words were presented in different sizes: the largest are those with the highest frequency in the corpus, and the smallest have lower frequencies, providing an idea of the content of the textual material|(21). The word cloud is shown in Figure 1.

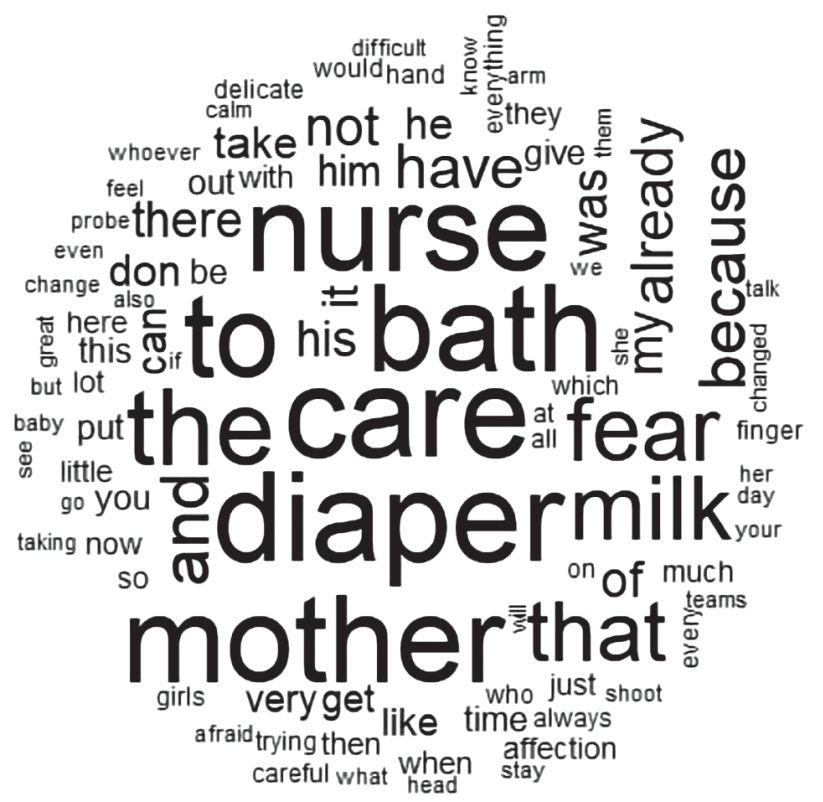

Figure 1 - Word cloud on the practice of family care for premature infants in a Neonatal Intensive Care Unit under the cross-cultural view, Feira de Santana, Bahia, Brazil, 2019

It is observed that the word "care" has greater size and centrality in the image, followed by significant words such as "diaper, bath and milk". Although other family members are present in the setting of the Neonatal Intensive Care Unit, the maternal figure stands out in the care of the baby, and these words - evidenced by the "cloud" denote the actions related to the maternal role that these women wish to maintain in the neonatal environment with your premature child; however, they need the support of health professionals, mainly the "nurse", aiming at the preparation for shared care.
In this context, the word "fear" stands out, which can mean a barrier to the family's insertion in the care of premature infants in the neonatal ICU, as well as signalling that the team needs to value the family's feelings in order to enable a congruent care, as Leininger says ${ }^{(13)}$.

From the factors present in the second level of the Leininger Sunrise model, it was possible to identify and describe the technological, social, economic and educational factors that influence the patterns and expressions of care and health. These factors are intertwined and directly affect family care while signalling aspects for congruent care, with a view to comprehensive, efficient and resolving care ${ }^{(16-17)}$.

\section{Family care in the neonatal unit (NICU)}

It was identified that a good part of the care provided by families is associated with the hygiene and feeding of the NB, even when conditioned to rules and routines imposed by the hospital, as shown in the following reports:

I only give the milk, because the [nursing] teams give a bath [...]. There [at the NICU] I take milk for him. I don't have enough to give it to him, but I'm trying. (E2)

Changing diapers with great care, with the navel, with the accesses, you have to be careful not to lose. (E11)

Another significant care recorded in the field diary and also mentioned in the interviews was the family's desire to remain in the neonatal unit environment, protecting and caring for the child, signalling how important physical presence is for the NB's recovery.:

I give affection, I talk a lot. I get there [at the NICU], I talk and he wants to smile. (E2)

I try to talk to him as much as possible, so that he feels close to me. I try to go there [in the NICU] as many times as possible. I stay there with him, even if I don't stay there talking, I sit there. (E8)

Some interviewees highlighted a frequent and pleasant care, also noticed during the observations, which was the realization of the Kangaroo position. This generated an expectation in the family to be able to help the NB's recovery, regaining control over their life; thus promoting their autonomy. Therefore, when receiving guidance from health professionals about this care, the family felt strengthened in their self-confidence and learned a new care, different from the usual, as observed in the statements:

I already carry him on my arms [...]. My heat passes to him, he doesn't lose weight, from the normal temperature outside. (E2)

The kangaroo method, I get him to get used to me and to be able to gain weight, you know, that helps and his metabolism. (E12)

Although some mothers reported positive attitudes in participating in the care, others reported feelings of "doing nothing", no significant care for their child, showing the lack of good guidance and support about the care actions by the health team, what keeps the family in an area of insecurity and non-involvement with the neonatal environment, demonstrated by the following excerpts: 
I can't do anything. Nothing at all. The only thing I managed to do was put him on my lap. Not even changing it, I managed to change it yet. (E6)

No, I do it, I just stay there looking and talking because I don't have much to do, what needs to be done, who does it is them [the nursing team], they do everything. (E9)

There were references to the parents' fear and lack of experience in staying and caring for the premature infant in the Neonatal Intensive Care Unit. This may be due to the fact that parents are experiencing motherhood for the first time, the peculiar characteristics of the premature baby and the context of hospitalization, leaving them inhibited and paralyzed in this scenario, as evidenced by the following reports:

I haven't done any yet, I haven't bathed him, until today I haven't changed diapers yet, for my fear. [...] they [nursing staff] say: "Mother, if you want you can change, you can change", but I'm still afraid. (E1)

I already put my little finger on his face. I already put my hand on it. So, this for me, it's already been wonderful. If I could I would do so much more. I don't do it anymore because of fear and because of lack of experience. (E12)

\section{(In)effective support for shared care}

The findings pointed out that the lack of knowledge about hospitalization and prematurity increases the fragility of the family, especially when faced with an unknown environment in the neonatal ICU, making mothers imagine that something bad could happen to their child. This situation can influence their lack of engagement in caring for NBs, as illustrated by the statements:

I despaired a lot at first, I didn't know what an ICU was, for babies who were serious, I was very desperate. (E2)

Because it was very difficult when I heard he was going to the ICU, because like that, when he actually goes, when the mother knows that he is going to the ICU the first time he gets a shock. (E1)

Another situation that emerged is related to the social and structural condition of families, such as geographical distance, accessibility and economic factors, bringing the elements of the second level of Leininger's Sunrise model, which influence the ways of caring in the individual and family context. So, it was observed in the visit times to the NB the low frequency of family members and, consequently, weakness in the insertion in shared care, as can be seen in the following report:

In this case, because this is the second time that I'm coming here. I can't come here as often. Even because the issue of displacement, expenses. [...] mainly me who live almost $400 \mathrm{~km}$ away, to move. It is not easy coming here to see my son. (E7)

Some families reported that they are not able to fully exercise the parental role, as they depended on the "release or not" of health professionals to take care of their own child, with the power of the team predominating over the family that impair shared care. This can be verified in the following lines:
For me, it's more or less, because that's the way it is, there are things they don't let us do, there are things they can. (E6)

No, it is because it is like this, every time you have to get it, you have to ask, then to get it, you have to get it like this, now he took a shower, then they: "Leave him alone, he took a shower, you know". (E8)

The use of "hard technology" associated with the lack of information about its functioning is able to "neutralize" families in the neonatal environment, something also referenced by crosscultural care, according to which technological factors negatively influence care, when there is an appreciation this, disintegrated from an educational posture that allows the involvement of family members in shared care.

We go, just give a little affection, and take the conversation and milk, because until then, we can't get there [from the incubator] because of those things, you know, the devices. (E9)

It was found that when health professionals are unable to help the family to experience the experience of hospitalization in a less traumatic way, through a good reception and effective communication, this generates negative feelings in the family regarding the care provided by the professionals and leaves them distant of child care. Once again, educational factors emerge, which may interfere with care, as reported below:

But, they [nursing staff] do not listen to what we say at all. [...] They treat us very badly. It is not good, this is not good for us. Do not pass a good security to us. (E6)

Unfortunately still, I can only touch him badly yet, because they [health professionals] told me not to even have this contact. (E14)

Another aspect reported by some family members and which shows a reductionist view of the dimension and importance of family care, is that, as they witness the attention given to the NB, while they are excluded from this care, any improvement in the child is attributed to the actions exclusive to the team, leaving the family only as a spectator. This situation was observed and recorded in a field diary:

But, take it like that, from time to time. Put it in your arms to feel, more, nothing else. Which is just looking, you know, the doctors taking care, with that affection, dedication. (E16)

It is very delicate [...]. Not so much for us mom, because we just come to breastfeed [milk]. It is more delicate who is really caring, nurses, technicians. (E13)

On the other hand, when there was dialogue and effective communication between some health professionals and the family in the care process, this allowed the formation of bonds and trust between them and, consequently, the success of shared care.

\section{DISCUSSION}

The family should be recognized by health professionals as a basic unit of cultural care that includes standardized and learned values, beliefs and ways of life ${ }^{(13)}$, offered to preterm infants during 
the entire hospitalization process, being considered, thus, as a minimizing agent of the newborn's suffering. For this, a paradigm shift is necessary: care is no longer centered on the phenomenon of the disease to focus on the patient and his family, aiming at the humanization of care, preparing family members for hospital discharge ${ }^{(24-25)}$.

Family care involves environmental and biopsychosocial actions that provide comprehensive care, contributes to the formation of a bond between NB and family, provides the baby's physical and emotional development, improving clinical treatment and decreasing hospitalization and re-admissions ${ }^{(26)}$.

When analyzing the data, it was possible to verify that - in the care practices performed by families that experience the hospitalization of a premature child in the NICU, in the perspective of cross-cultural care - the moments when the family feels welcomed and prepared to participate in the care of the NBs are related to the receptivity promoted by the nursing team, when advising on the unit's routines as well as favoring an interpersonal relationship and the acquisition of a bond. However, there are other moments in which it is noticed that the team excludes the family from this process, without involving the members in the care, in the participation in the planning and in the decision making. This attitude deprives the team of gaining awareness about its role in the care process, often associated with the complexity of care for extreme premature NB, due to the use of high technology or the severity of the diagnosis.

During the observation in the field, it was noticed that part of the care delegated to the family are those considered relevant by the professionals and involve, in most cases, hygiene and food actions, disregarding the importance of building the therapeutic plan shared between the team and family members. These are measures linked to health policies from a theoretical perspective: they encourage restricted and specific care, seek to meet outdated standards, routines and protocols, without valuing the family's needs and prior knowledge ${ }^{(27-28)}$.

A recent study informs that allowing the family to place the NB in the kangaroo position from the first week of life, whether the baby is on mechanical ventilation or not, strengthens the bond and autonomy to care for the child; and preventing the mother from performing actions related to the maternal role generates feelings of loss of maternal function ${ }^{(29)}$. So, it is necessary to introduce, from the beginning of hospitalization, the family in care, regardless of the child's clinical conditions, using caution and common sense by the professionals.

Thus, the care provided by health professionals is far from that recommended by Leininger ${ }^{(13)}$, because the focus is still centered on the disease and the NB. This reveals that it is necessary to move forward to include the family as a care unit, considering their culture and the care needs of each person ${ }^{(17)}$. To change this reality, it is necessary to raise awareness, equip and keep the team up to date, so that it recognizes the family as a complex unit and that needs to be strengthened in order to take care of this new member, being respected and providing care that is significant.

In order to implement culturally congruent care, as proposed by Leininger, the FCC strategy will help health professionals both to reflect on shared care between staff/patient/family and to create protocols as well as new more flexible rules and routines within the NICU. In this sense, it is important to train up-to-date care practices, demonstration of good practice and permanent education manuals for the team, in order to improve and qualify the care provided in the neonatal environment ${ }^{(30)}$.

Thus, health professionals will be able to help the family in coping with this situation through welcoming and effective communication, which are principles that govern the FCC. They will provide comfort and safety in the hospital environment, which is considered strange and hostile, will generate bonds with the team, will alleviate the suffering experienced by the families, in the perspective of the comprehensiveness and reciprocity of care for the NB in the health-disease process, improving the assistance provided $^{(31-32)}$. When communication fails, each professional brings only what belongs to their line of care, making it fragmented and compromising the final result ${ }^{(33)}$.

Still, it is emphasized the existence of aspects that make it difficult for parents to stay in the neonatal unit, such as issues related to work, place of residence, financial situation and responsibility for other children. The low paternal participation in the care of premature infants during hospitalization was noteworthy, because of the father's return to work activities after five working days of birth. Thus, it is necessary to expand the forms of social support of the institution towards families, such as the construction of support groups, socialization of information about hospital services, as well as post-discharge monitoring ${ }^{(34)}$.

\section{Limitations of the study}

The limitation of this research is understood as the election of a single institution with family members of premature infants, which portrays a local reality, therefore, it is necessary to investigate in different scenarios, which may point to other practices. In addition, the reduced number of male participants in the study can be mentioned, as, in the context of hospitalization, the father returns to work activities, while his partner needs to be present in the neonatal unit.

\section{Contributions to the fields of Nursing, Health or Public Policy}

This study offers contributions to the practice of nursing, as it provides the reflection of professionals regarding the promotion of shared care involving the family in the care provided to premature infants in the NICU, to overcome the dominant ideological aspect in this care scenario. In addition, the present study leads nurses to rethink their practices, in order to modify them with the aim of inserting the family as an active subject in the premature care process, offering safer and more humanized care, preparing them for discharge and approaching what Leininger proposes as congruent care.

\section{CONCLUSION}

It was observed that the care provided by family members was carried out when requested by the team and not systematized in the planning, unveiling a care policy that keeps the mother as a passive subject of the process and the professionals as the holders of power Beyond that, they adopt vertical and prescriptive actions, aiming at the demand and the need of the institution, without 
valuing the autonomy and needs of each family. However, it was also noticed the existence of isolated actions that inserted the family in care, trying to adapt modes of care within the permitted conditions and respecting scientific precepts.

In view of the objective of this study, it should be emphasized that Leininger's cross-cultural theory can be applied by nurses to contribute to the provision of assistance to family members of premature NBs admitted to the NICU. Also, the results reinforce the need to implement Family Centered Care in the NICU, so that, thus, health professionals involve the family in the context of shared care.

\section{FUNDING}

His is a research funded by the Research Support Foundation of the State of Bahia (FAPESB), call 003/2017, through a Master's Scholarship.

\section{REFERENCES}

1. Oliveira K, Veronez M, Higarashi IH, Corrêa DAM. Vivências de familiares no processo de nascimento e internação de seus filhos em UTI neonatal. Esc Anna Nery. 2013;17(1):46-53. doi: 10.1590/S1414-81452013000100007

2. Maia JMA, Silva LB, Ferrari EAS. A relação da família com crianças hospitalizadas na unidade de terapia intensiva neonatal com a equipe de enfermagem. Rev Enferm Contemp. 2014;3(2):154-64. doi: 10.17267/2317-3378rec.v3i2.336

3. Santana JO, Borges KI, Souza DA, Pinto KRTF, Rossetto EG, Zani AV. Paternal care for hospitalized premature children: maternal representations. Rev Baiana Enferm. 2017;31(4):e22310. doi: 10.18471/rbe.v31i4.22310

4. Lelis BDB, Sousa MI;Mello DF, Wernet M, Velozo ABF, Leite AM. Acolhimento materno no contexto da prematuridade. Rev Enferm UFPE[Internet]. 2018 [cited 2019 Sep 20];12(6):1563-9. Available from: https://periodicos.ufpe.br/revistas/revistaenfermagem/article/ view/230763/29182

5. Balbino FS, Meschini GFG, Balieiro MMFG, Mandetta MA. Percepção do cuidado centrado na família em unidade neonatal. Rev Enferm UFSM. 2016;6(1):84-92. doi: 10.5902/2179769216340

6. Zanfolim LC, Cerchiari EAN, Ganassin FMH. Dificuldades Vivenciadas pelas Mães na Hospitalização de seus Bebês em Unidades Neonatais. Psicol: Ciên Prof. 2018;38(1):25-35. doi: 10.1590/1982-3703000292017

7. Pacheco STA, Rodrigues BMRD, Dionísio MCR, Machado ACC, Coutinho KAA, Gomes APR. Family-centered care: nursing application in the context of the hospitalized child. Rev Enferm UERJ [Internet]. 2013 [cited 2019 Aug 27];21(1):106-12. Available from: https://www.epublicacoes.uerj.br/index.php/enfermagemuerj/article/view/6443/5902

8. Ministério da Saúde (BR). Secretaria de Atenção à Saúde. Departamento de Ações Programáticas Estratégicas. Atenção humanizada ao recém-nascido: Método Canguru: manual técnico[Internet]. 3. ed. Brasília: Ministério da Saúde. 2017 [cited 2019 Sep 06]. Available from: http://bvsms.saude.gov.br/bvs/publicacoes/atencao_humanizada_metodo_canguru_manual_3ed.pdf

9. Barbosa MAM, Balieiro MMFG, Pettengill MAM. Family-centered care in the context of children with disabilities and their families: a reflective review]. Texto Contexto Enferm. 2012;21(1):194-9. doi: 10.1590/S0104-07072012000100022

10. Sampaio AA, Zonta JB, Ferreira FY, Okido ACC. Family-centered care in a pediatric intensive care unit: professionals' perceptions. Rev Rene. 2017;18(4):515-20. doi: 10.15253/2175-6783.2017000400013

11. Sousa FCP, Montenegro LC, Gouveia VR, Corrêa AR, Rocha PK, Manzo BF. Family participation in patient safety in neonatal units from the nursing perspective. Texto Contexto Enferm. 2017;26(3):e1180016. doi: 10.1590/0104-07072017001180016

12. Lee LA, Carter M, Stevenson SB, Harrison HA. Improving family-centered care practices in the NICU. Neonatal Netw. 2014;33(3):125-32. doi: 10.1891/0730-0832.33.3.125

13. Leininger MM. Culture care theory: a major contribution to advance transcultural nursing knowledge and practices. J Transcult Nurs. 2002;13(3):189-192. doi: 10.1177/10459602013003005

14. Henckemaier L, Siewert JS, Tonnera LCJ, Alvarez AM, Meirelles BHS, Nitschke RG. Cuidado transcultural de Leininger na perspectiva dos programas de pós-graduação em enfermagem: revisão integrativa. Rev Ciên Saúde. 2014;7(2):85-91. doi: 10.15448/1983-652X.2014.2.15772

15. Seima MD, Michel T, Méier MJ, Wall ML, Lenardt MH. A produção científica da enfermagem e a utilização da teoria de Madeleine Leininger: revisão integrativa 1985 - 2011. Esc Anna Nery. 2011;15(4):851-857. doi: 10.1590/S1414-81452011000400027

16. Betiolli SE, Neu DKM, Meier MJ, Wall M L, Lenardt M H. Decisões e ações de cuidado em enfermagem alicerçadas em Madeleine Leininger. Cogitare Enferm. 2013;4(18):775-81. doi: 10.5380/ce.v18i4.34936

17. Morais AC, Camargo CL. O cuidado às crianças quilombolas no domicílio: um estudo transcultural. Rio de Janeiro: Bonecker; 2017. 177p.

18. Tong A, Sainsbury P, Craig J. Consolidated criteria for reporting qualitative research (COREQ): a 32-item checklist for interviews and focus groups. Int J Qual Health Care [Internet]. 2007 [cited 2019 Aug 27];19(6):349-57. Available from: https://academic.oup.com/intqhc/ article/19/6/349/1791966

19. Pereira Neto EF, Ramos MZ;Silveira EMC. Configurações familiares e implicações para o trabalho em saúde da criança em nível hospitalar. Physis Rev Saúde Coletiva. 2016;26(3):961-979. doi: 10.1590/s0103-73312016000300013

20. Bardin, L. Organização da análise. São Paulo: Edições 70;2011. 279p. 
21. Camargo BV, Justo AM. Tutorial para uso do Softwere IRAMUTEQ (Interface de R pour les Analyses Multidimensionnelles de Textes et de Questionnaires). Laboratório de Psicologia Social de Comunicação e Cognoção - UFSC [Internet]. 2018[ cited 2019 Aug 12]. Available from: http://www.iramuteq.org/documentation/fichiers/tutoriel-en-portugais

22. Tomicic A, Bernardi F. Between past and present: the sociopsychological constructs of colonialism, coloniality and postcolonialism. Integr Psych Behav [Internet]. 2018 [cited 2019 Jun 06];52(1):152-75. Available from: https://www.ncbi.nlm.nih.gov/pubmed/29063442

23. Salvador PTCO, Vítor AF, Ferreira Jr MA, Fernandes MID, Santos VEP. Systematization of teaching nursing care at a technical level: perception of professors. Acta Paul Enferm. 2016;29(5):525-33. doi: 10.1590/1982-0194201600073

24. Leite CPL, Souza SNDH, Rossetto EG, Pegoraro LGO, Jacinto VCB. The baby's diary to the premature infant's mother: supporting familycentered care. Rev Enferm UERJ. 2016;24(1):e8664. doi: 10.12957/reuerj.2016.8664

25. Balbino FS, Balieiro MMFG, Mandetta MA. Measurement of Family-centered care perception and parental stress in a neonatal unit. Rev Latino-Am Enferm. 2016;24:e2753. doi: 10.1590/1518-8345.0710.2753

26. Araújo BBM, Rodrigues BMRD, Pacheco ST. Promoting mothers' care for premature neonates: the perspective of problem-based education in health. Rev Enferm UERJ. 2015;23(1):128-31. doi: 10.12957/reuerj.2015.14779

27. Araujo BBM, Pacheco STA, Rodrigues BMRD, Silva LF, Rodrigues BRD, Arantes PCC. The nursing social practice in the promotion of maternal care to the premature in the neonatal unit. Texto Contexto Enferm. 2018;27(4):e2770017. doi: 10.1590/0104-07072018002770017

28. Farias DHR, Gomes GC, Almeida MF, Lerchlunardi V, Xavier DM, Queiroz MVO. Barreiras presentes no processo de construção do cuidado familiar cultural à criança no hospital: abordagem transcultural. Aquichan. 2019;19(1):e1912. doi: 10.5294/aqui.2019.19.1.2.

29. Kegler JJ, Neves ET, Silva AM, Jantsch LB, Bertoldo CS, Silva JH. Stress in parents of newborns in a Neonatal Intensive Care Unit. Esc Anna Nery. 2019;23(1):e20180178. doi: 10.1590/2177-9465-EAN-2018-0178

30. Silva TRG, Manzo BF, Fioreti FCCF, Silva PM. Family-centered care from the perspective of nurses in the Neonatal Intensive Care Unit. Rev Rene. 2016;17(5):643-50. doi: 10.15253/2175-6783.2016000500009

31. Baylis R, Ewald U, Gradin M, Hedberg Nyqvist K, Rubertsson C, Thernström Blomqvist Y. First-time events between parents and preterm infants are affected by the designs and routines of neonatal intensive care units. Acta Paediatr. 2014;103(10):1045-52. doi: 10.1111/ apa.12719

32. Rodrigues BC, Uema RTB, Rissi GP, Felipin LCS, Higarashi IH. Family centered care and practice in the neonatal intensive care unit. Rev Rene . 2019;20(1):e39767. doi:10.15235/2175-6783.20192039767

33. Dudley N, Ackerman A, Brown KM, Snow SK. Patient-and family-centered care of children in the Emergency Department. Pediatrics. 2015;135(1):e255-72. doi: 10.1542/peds.2014-3424

34. Raffray M, Semenic S, Osorio Galeano S, Ochoa Marín SC. Barriers and facilitators to preparing families with premature infants for discharge home from the neonatal unit: perceptions of health care providers. Invest Educ Enferm. 2014;32(3):379-92. doi: 10.17533/udea.iee.v32n3a03 